\title{
A LITERARY ANALYSIS ON FIGURE OF SPEECH IN KAKAWIN NITISASTRA
}

\author{
by \\ I.B. Arya Lawa Manuaba1); I Nyoman Sudirman²) \\ 1) 0824128803, Prodi Pendidikan Bahasa Inggris STKIP Suar Bangli, Bali \\ 2)0815108301, Prodi Pendidikan Bahasa dan Sastra Indonesia STKIP Suar Bangli, Bali
}

1)aryamanuaba@stkipsuarbangli.ac.id

\begin{abstract}
Kakawin Nitisastra, one of ancient Javanese scriptures, holds a lot of figurative writings in it. Revelation and analysis of those figurative language are important to enrich Indonesian literary culture and introduce it to character education in present days. The aims of this study are (1) to identify types of figure of speech used in Kakawin Nitisastra, (2) to identify functions of those figurative speech, and (3) to reveal the meanings behind them. By applying literature-based qualitative method, the result of this study reveals that Kakawin Nitisastra contains mostly similes, symbolism, allegory, hyperboles, and personifications related to animals, plants and ancient beliefs in the Vedas. The figures of speech have at least four functions namely to give examples, to compare qualities, to criticize, and to remind readers about proper deeds in the society.
\end{abstract}

\section{Introduction}

\subsection{Background of study}

In the ancient ages, literature was inseparable from scholarly conducts. Prominent scholars and rakawis 'poets' were regarded as a highly intelligent people who could bring life into words and tones, express feelings or rasas in traditional poetry, write religious teachings in the forms of kakawins (verses in ancient Javanese language which to be chanted in various ways of singing called meters), and report important events such as enthronement of a king, natural disasters, and many other influential events (Zoetmulder, 1983: xi). Some lines from Kakawin Desawarnana or broadly known as Nagarakretagama are examples of these valuable records. The work describes clearly a detailed report about the pilgrimage of King Rajasanagara, the fourth king of Majapahit, around Java (Mulyana, 2006: 32). Another instance is the manuscript of Sutasoma by $\mathrm{Mpu}$ Tantular in which a blend composition of Hindu and Buddhist religious teachings is found. Many other similar scriptures from more or less the same ages are available in their transliterated forms in Kirtya, Singaraja, and accessible with permissions.

Beside those functions, kakawins are also used as media of transferring knowledge as well as values of morality and religion (Tim Pengkajian, 2002: 3). There are abundant of religious teachings written in four-lined verses of this kind and are sung in different meters. Kakawin Bubuksah is one example, containing metaphorical illumination of nonviolence as per Hindu perspective. Nirarthaprakreta by Mpu Nirartha contains moral 
teachings for common people and also the anonymous Nitisastra which has figurative content about moral teachings and advice for leadership and proper conducts in the society.

One of the ancient literary works of Javanese ancestors in literature is Kakawin Nitisastra. Written in old Javanese language (kawi language, or the language of the poets), this piece of literary work of the fifteenth century is worth-reading due to its complexity of figurative allures. Even though this kakawin was compiled in the heyday of Majapahit's literature development in the fifteenth century, it amazingly has neither a clear colophon nor sign of authorization. In fact, it is nearly anonymous though some scholars, mainly Robson (1978) and Zoetmulder (1983) suggest that the author was a high priest of the kingdom, otherwise it would not have been possible (and proper) to advise a king in spite of being figuratively delivered.

Nevertheless, Kakawin Nitisastra has gained fame among historians, authors, literary teachers and even theists. Its content is mainly derived from ancient Sanskrit text of the same name, and because of its exceptional moral topics foiled in figurative beauty, this scripture does have its own position in the world of ancient Indonesian literary discourse studies. The fame and worthiness of Kakawin Nitisastra is due to many factors. Firstly, it contains many analogies, similes and metaphors that bring satiric effects in the statement of the author. They, however, are written in well-organized figure of speech which make this kakawin is so exquisitely rich in figurative sayings that it seems not to directly offend anyone's feeling. The use of such figurative expressions strengthens the unique position among the other ancient Indonesian (in this case, Javanese) literary works.

Zoetmulder (1983: 267) explains that any kinds of kakawin do commonly consist of figure of speech by taking distinctive characters, shapes or behaviors of animals, plants or natural phenomena as reference. In Kakawin Nitisastra, the same occurrence is obious in many parts. The poet frequently used animal and plant characteristics and traits to imply to human qualities, for example,

\section{Chapter 1 Verse 2 Line 1-2:}

ring wwang tan wruha ring subhāsita mapunggung mangraséng șadrasa tan wruh pangrasaning sêdah pucang adoh tambūla widyāsêpi

The poet uses metaphorical phrase adoh tambūla 'far from the delightful taste of betel nuts' to refer to someone who is not interested in learning religious teachings (widyāsêpi). The word tambūla refer to a set of betel leaves and betel nuts, combined with a pinch of thick edible lime dough, has been considered a very prestigious token of respect in the ancient Javanese, Balinese or even Sumatranese people (Mulyana, 2002) and from the prestige of betel leaves 'jambe' the name Jambi emerged in Sumatra and the word jambe is often added to medieval royal Balinese names. A traditional householder would serve tambūla for an important guest to chew as an honor and respect because the taste of the betel leaves and its mixture was considered refreshing. Thus, based on this semantic meaning of tambüla, the poet compared someone who has no interest in religious teachings as adoh 
tambūla, meaning 'never eating betel leaves' (Mardiwarsito, 1990:579). So, the presence of figurative language has an important role in literary works to enhance the meaning of utterances. Also, figure of speech enables an utterance to contain deeper and more vivid ideas so as to deliver meanings which cannot be expressed by merely literal meaning (Perrine, 956: 56-57).

The second reason of why Kakawin Nitisastra is chosen is because it holds essential values in daily life of people in general. Piloyo (2004: 154) states that Kakawin Nitisastra contains moral values that depict Indonesian culture and thus can raise idealism and cultural dignity. Furthermore, Kakawin Nitisastra is considered as one of valuable literary works for people who want a universal moral and spiritual guidance in his life (Tim Pengkajian, 2002).

In fact, unfortunately, Kakawin Nitisastra is only known in its original verses in Balinese alphabetical transliteration. This version is compiled by Tim Penyusun Kakawin Nitisastra Dinas Pendidikan Dasar Provinsi Bali (1999) and is commercialized in many bookstores in Bali. This version, though considered as the most reliable one, is not understandable by people who do not read in Balinese alphabet. Another hindering factor of this version is that the translation of the kakawin script is also in Balinese alphabet and Balinese language (basa Bali) of the highest stratum. So to write, this version is practically applicable only for some groups of Balinese people or those who can read in Balinese. An available translation and transliteration of the kakawin is provided by PGAHN 6 Tahun Singaraja in 1971 in Latin characters. Yet it contains a lot of misspellings and mistranslations.

Considering values of Kakawin Nitisastra as a heritage of the olden times, deeper analysis and studies on this literary work is needed to reveal its importance in today's society. Revelation on the meanings of its scattered figures of speech may contribute to enrichment of Indonesian literature and linguistic reference. Therefore, this study aims firstly to discover types of figure of speech used in Kakawin Nitisastra. Then, the functions of the figures of speech are put into analysis. Once this is accomplished, the meanings of the figures of speech will be revealed, especially in moral and/or religious context.

\subsection{Research significance}

As character education is being promoted in Indonesian educational environs and culture, it is a necessity for teachers and other types of educators to include character and moral values in teachings. How the teachings can be conducted and enriched with moral proverbs and stories could enact as reminder and powerful media for students to reflect on their own characters. This study provides necessary English translation of nearly all content of Kakawin Nitisastra which contain apparent (or implied) figures of speech.

While character education is important on students' and teachers' side, it is also equally beneficial for parents. Indonesian parents who request their children to be updated to developing world without leaping away from their cultural identity can have good benefit from this research. 


\subsection{Definition of key terms Kakawin}

The term kakawin, according to Mardiwarsito (1990:

274) is etymologically derived from Sanskrit lexeme kawi 'poet'. It is then acculturated to old Javanese language with the same meaning. The term kakawin is a compound word with prefix $k a$ - and suffix -an functioning as noun formative. So kakawin in old Javanese means 'chanted poem'.

In addition, Zoetmulder (1983: xi) defines kakawin is also known as kalangwan or kalangon 'beauty'. Kakawins as a type of literary works I considered beautiful since it brings someone to an ecstasy (lango) and get immersed in the taste of self-mirroring and meanings. The word kalangwan itself is an old Javanese word meaning 'beauty' (Mardiwarsito, 1990: 310).

A more complete definition of kakawin is provided in Zoetmulder (1983) as a four-lined metrical verse with the same amount of syllables in each line. Every syllable in a line is tied by metrical rules named guru-laghu, or wrêta-matra. The fixed rules of guru-laghu determine whether a syllable is sung with a long, weighty and wavy voice (guru) or short and light voice (laghu). The position of guru-laghu are fixed in every line and contribute to all lines in a verse. Guru is usually symbolized as dash (-) and laghu as $(\mathrm{U})$. A symbol $(\underline{\mathrm{U}})$ means the syllable could be both treated as guru or laghu.

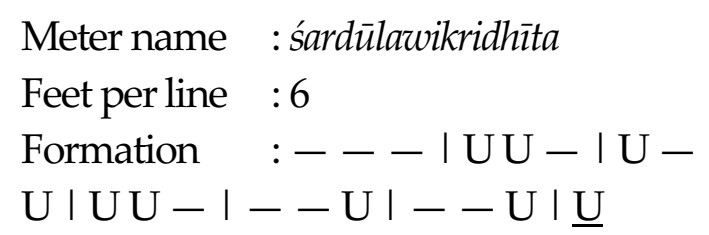

jroning wwé parimāna kāla gaganing tuñjung dawut kawruhi

yan ring jātikula pracāra winaya mwang sî̀la karménggita

yan ring panditia ring kșamā mudita śāntopekșa ris mārdaza

sang śāstrajña wuwus nirāmrta paḍnyāngdé sutuṣténg prajā (Ch. 1 V. 6)

[The depth of a pond can be meausured by picking a water lily stalk growng in it. The faily origin of a man is known from his behavior, wisdom, manners and attitude. Characters of a saintly person is forgiving, fixed in happiness, peaceful, tolerant, and compassionate. He who masters spiritual knowledge is noticed from his pleasing words as a splash of water of eternity (amrta).]

It is unknown how kakawin chanting styles used to be sung in old Javanese period. In fact, however, the way kakawin tradition has been preserved in Bali for about 500 years indicate similarities, though not likely the same, to its ancestors in Java.

\section{Nitisastra}

Despite its wide range of popularity for about five hundred years, and its ancient origin from Indian Manusmrti centuries before its translation in Javanese language was available, Nitisastra versions are still rare compared to others. Nitisastra (IAST nītiśāstra) is a derivation from two Sanskrit lexemes nìti and śāstra (Mardiwarsito, 199: 375) meaning 'ethics' and 'knowledge'. In fact, Nitisastra itself appears more to be a kind of literary genre rather than a scripture.

Some scriptures falling into Nitisastra category are, for instance, Canakya Nitisastra, compiled by Chanakya 
Pandit in the second century B.C. during the reign of Indian famous Candragupta dynasty. Some scholars, including Robson (1978) suggests that Kakawin Nitisastra is one of the most similar adaptations of Chanakya Nitisastra, in spite of being made more compact and briefer. Both contain advice, wise words and criticism towards the king and government administrators (Davis, 2009). Another example of Nitisastra is the Arthasastra which is commonly regarded as similar to Chanakya Nitisastra. Also, both scriptures, the Kakawin Nitisastra and Chanakya Nitisastra contain almost the same figure of speech and metaphorical comparisons, indicating that they both share common thoughts.

\section{Figure of speech}

Perrine (1956: 56) describes that someone who uses figure of speech in one's utterances as saying less or more than one actually means, saying the opposite meaning of one's utterance or it might be something completely different from what one actually means. Furthermore, Perrine adds that figure of speech is a form of speech aiming at expressing something whose meaning cannot be taken only from literal meaning.

Another definition is by Frederik (1988: 36-37) that figure of speech is literally untrue and it is common especially in poetry. Therefore, poetry is said to be massive resource of figurative language. Additionally, Waluyo (1987: 83) stated that figurative language is poems contributes to various meanings since it can be differently (or contextually) interpreted.

Several reasons contribute to variegated uses of figure of speech.
Perrine (1974: 616-617) denotes that figurative speech triggers imaginative pleasure, as joy or silliness in utterances (e.g. John speaks Spanish as fluent as a pig can squeak). Also, figure of speech is a way to produce additional imagery to a poem, and thus making a poem worth-reading due to its ability to express a lot of things that what it literally states. Therefore, figure of speech intensifies a person's feeling and idea coverage expressed in one's simple utterances.

Allegory

Allegory is a narrative or description that has second meaning beneath the surface meaning (Perrine, 1983: 83). Commonly, an allegory is present in the form of paragraph or lines. Waluyo (1987: 144) defines allegory as a narration from the plot of which someone may draw moral or religious value. The Arabian story collection of 1001 nights is an example of allegorical compilation enacted mostly by animal characters. Tantri story from ancient Bali and Pancatantra of Indian origin are another set of tales reflecting human reality figured in fable characterization.

\section{Apostrophe}

Apostrophe means 'to call something or someone absent' (Perrine, 1983: 60) as if it were present and could reply what someone says. In any literary works, sometimes the writer addresses someone or something nonexistent or dead, but the writer regardsit as alive. The effect of apostrophe is the existence of questionings in a poem of story, but it seems that there is no answer of those questions. 
Personification

Frederik (1988: 48) describes personification as a figure of speech that bestows human traits on anything nonhuman. In the other words, it gives human attributes and characters to animals, objects or concepts.

Technique of personifying nonhuman participants in literary works is very often used by most writers. It seems that applying human characters to things or animals has a contribution to enrichment and realization of meaning.

An opposite for personification is zoomorphication, applying non-human characters to human beings.

\section{Symbolism}

The use of symbol is an effective way to describe and strengthen meanings. Symbol means something in actual (denotative) meaning as well as the connotative meaning (the meaning beyond the literal meaning). Frederik (1988: 50) chose the term 'literary symbol' rather than merely 'symbol' since its literary symbol definition is narrower. She describes symbol as a thing (an event, a person, a quality) that functions simultaneously in two ways: as itself and as a sign of something outside itself.

In most literary works, symbols are used to depict things or situation because ordinary words are insufficient to represent what the writer intends to say (Waluyo, 1987: 87). There are symbols of sound, things, sounds and nuances as four types of commonly used symbols in literary works.

\section{Simile}

Simile means to compare things that are essentially unlike (Perrine, 1983:
57). Simile is characterized by the use of (be) like, resemble, similar to, as and so on. So, simile is a way to state that something is like something else.

\section{Metaphor}

When likeness and comparison between two things' characters or manifestation is implied, it is called metaphor. It omits the comparative words and implies directly that one thing is another. Thus, a simile says that $\mathrm{x}$ is like $\mathrm{y}$, but metaphor says $\mathrm{x}$ is $\mathrm{y}$ (Frederik, 1988: 37).

\section{Hyperbole}

Hyperbole is also known as overstatement, an opposite to litotes (understatement). It is an exaggeration of a truth which is made to give strong (sometimes over) emphasis to a certain thing.

"May you reign 'till the stars fall from the sky."

- The Chronicle of Narnia.

\section{Allusion}

Allusion is a literary device that stimulates ideas, associations, an extra information in the readers' mind with only a word or two (Willis, 2009). Allusion means reference. Readers of literary works are expected to be familiar to allusions. If they are unfamiliar to allusions being presented, the meaning behind the allusion is unknown. Writers usually refer to other people's literary works, public figures, or particular events to create allusions. 
Paradox

Paradox is an apparent contradiction that is nevertheless somehow true (Perrine 1983: 95). A paradox can be in the form of a statement or situation, but mostly paradox occurs in sentence. A paradox seems contradictory at the beginning, but actually the meaning behind it is logic.

\section{Research Method}

This research is qualitative in nature, and the analysis is literary-based with ground theory type of method. So the analysis is based on a certain theory of figure of speech, aiming at finding out meanings in the subject of the study. Literature-based analysis is used since the old Javanese society where kakawin tradition once thrived has vanished. So to say, the active speakers of the language as well as the social setting in which the language was once used had been lost for about five centuries. Therefore, the reference of the old Javanese social background is known only from surviving documents and literary works.

Apart from Kakawin Nitisastra as the subject of the study and the primary data source, peripheral data is also essential to the completeness of the analysis, including some related literature which are useful in the enrichment of the analysis.

\section{Findings}

\subsection{Figure of speech found in Kakawin} Nitisastra

The most common types of figurative language found in Kakawi Nitisastra is simile (in 14 verses), metaphors (in 15 verses) and symbolism (in 16 verses).

\section{Similes}

Interestingly, Kakawin Nitisastra has a lot of ways to say similes. There are many synonymous words to connect similarities between two things.

yan wéntên mawiwéka śāstra nirapékșa byakta monabrata (Ch. 1 Verse 2).

[If there is someone talking about spiritual knowledge, a less intelligent man is silent as someone who is doing silent meditation].

yan ing madhyan ikang musuh mucapakên wāk śurasingākrrti (Ch. 1 Verse 4)

[Facing before your enemy, utter your words as boldly as a lion's roar].

sang śāstrajña wuwus mirāmrta padanyāngdé sutușténg prajā (Ch. 1 Verse 6)

[The words of he who masters spiritual knowledge is compared as water of eternity that makes people relieved].

yan kita ninda ring guru patinta maparêk atêmu

lwir nika wangśa patra tumibeng watu rêmêk apasah (Ch. 2 Verse 13)

[If you blaspheme a spiritual master, your destruction is certain for you, as a ceramic plate smashed onto a rock].

wwayagêng atiwéga tambakana bêngkungên upamaning artha sêtuha (Ch. 3 Verse 8) [Accumulated wealth resembles a big amount of water, being collected without being spent.]

wrkșa candana tulya sang sujana, sarpa mamilêt ing $i$ sor mangāśraya (Ch. 4 Verse 23). 
[A good man is like a sandalwood tree. Even snakes can come under it to take shelter].

...suśila kadi panêdêngning kusuma-wicitra (Ch. 5 Verse 6).

[Good behavior is like a blooming flower]

damar uga himpêr nikanang aśabda (Ch. 5 Verse 2)

[A quiet person resembles a candle].

sākșat dagdha gêsêng tikang wadana yan tika tan anginangérikang śabha

sākșat dagdha gêsêng tikang mukha yadin prihawak anginangérikang śabha

sākssat dagdha gêsêng wwong anwam $i$ wahaynya dumadak ika hīna kāsyasih

sākșat dagdha gêsêng tikang huwus jaḍpikun dumadak anêmu bhāgya wīryawān

(Ch. 8 Verse 2)

[Like being burnt your face if you do not eat betel leaves together in a meeting. Like being burnt your face is if in a meeting you eat betel leaves alone while no one does. Like being burnt a young man is if in his old age he becomes dreadful and pitiful. Like being burnt an old man is if he suddenly obtains wealth and strength in his very old age].

wadhu-jana dhana kadi loșta tanpa don (Ch. 8 Verse 4)

[For a detached person, women and wealth are as rocks without value].

kadi sang hyang indra sang amūkti sukha wibhawa...

ati yowana tuha-sudharma padan ira bhatara késawa (Ch. 9 Verse 1)

[Someone who is happy, powerful, opulent an heroic resembles Lord Indra, the king of heaven. A wise young man resembles Lord Visnu].

padaning kuputra taru-śușka tumuwuhi ri madhyaning wana

ikanang suputra taru-candana... (Ch. 12 Verse 1)

[A bad child is like a dry tree growing in the middle of a forest, while a good child is like a sandalwood tree].

\section{Allegory}

Allegorical sentences in Kakawin Nitisastra are of many varieties and systematically related to existence of animals, trees, natural phenomena and even demigods.

yan ring gorawa ghora śabdanika gong alpa kșiranyākêdik (Ch. 1 Verse 9)

[A cow with huge sound produces little milk].

kokila ring swaranya maka-rūpa kinalêwihakên

strī maka-rūpa diwya kapatibrata linêwihakên (Ch. 2 Verse 6)

[A myna bird is praised due to its special sound, and a woman is praised because of her devotion and faithfulness].

sêkar ing śamī murub abang tan hana wangin ika (Ch. 2 Verse 7)

[Silk cotton flowers are red but they have no fragrance].

mìna balanya ring banyu-magong maputêran adalêm (Ch. 2 Verse 10)

[The strength of a fish is in big, deep, and swift water]

têgal tan hana ning dukutnya tinilar têkap $i$ paśu taman hanānglawad 
nadì tan hana toya suśka tinilar sarasa hiku duméh padāsêpi (Ch. 3 Verse 1)

[A savanna without grass is left by animals. An arid river is left by water birds and becomes quiet].

warāmṛta mawor lawan wișa tangāmṛta tikang alapên têkapnira

ikā kanaka lén purișya mapulang kanaka juga kapeta kumbahên (Ch. 3 Verse 9]

[If there is nectar mixed in poison, take the nectar out of it. If a piece of gold falls down into a pile of feces, take the gold only and wash it].

\section{Symbolism}

The poet uses symbols of things at most, especially animals and plants. In Ch. 2 Verse 7 there is a sékar ing śami murub abang 'bright red silk-cotton flowers' indicating a person who is very glamour but has no significance in life. The color abang 'red' is used because it is considered brave and bold, emphasizing an exceptional attention for the readers.

The symbol amrta 'nectar of eternity' (Ch. 1 Verse 6) is used as a symbol of good person, good utterance, good teaching or help. For the poet, amrta could mean an allegory because all Hindus understand that amrta is nectar of eternity as mentioned in famous Vedic historical accounts.

Animals such as garddhaba 'donkey', kāka 'crow', and simha 'lion' are used in many verses to indicate symbolism of different characters of a person. A donkey is lazy and stupid, a crow is cunning and evil, and a lion is brave. Some other symbolism use trees like candana 'sandalwood' and śami 'silk cotton', and taru-suṣka 'dry tree'. The symbol of damar 'oil lamp' (Ch. 5 Verse 2) is also used as a comparison to the light of spiritual teachings.

\section{Apostrophe}

sêmbah ni nghulun ing bhațāâra hari sarwajūātma bhūh nityaśa (Ch. 1 Verse 1)

[I offer my obeisance to Lord Visnu, the Soul of all living entities who gives knowledge].

In this verse, the poet addresses Lord Visnu at the very beginning of his work, as if talking to God, praising Him and asking for permission to begin writing.

\section{Personification}

singha mwang wana tan patūt paḍa wirodhāngdoh tikāng keśari (Ch. 1 Verse 10) [If the lion and the forest do not get along each other, the lion flees afar and the forest is damaged].

nora na mitra manglêwihané wara-guna maruhur

nora na śatru manglêwihané gêlêng hana ri hati (Ch. 2 Verse 5)

[There is no better friend than good characters. There is no worse enemy than envy.]

śabdan i sang sujana mêpêk ing bhuwana (Ch. 2 Verse 11)

[Wise words of a saintly person fills the entire world].

\section{Paradox}

widyawișa tulya den ikang anabhyāsāla (Ch. 1 Verse 3)

[Knowledge is poison for a less intelligent person]. 
ikang umênêng lyabbhana ya matumpuk (Ch. 5 Verse 2)

[A quiet person will certainly be piled with wealth].

ring wwang wastu ngizwêh hinuttama hane déhanya nityénênêb (Ch. 13 Verse 9).

[The greatest obstacle of a man is always held out inside himself].

\subsection{Functions and meanings of the figures of speech}

The analysis of functions and meanings attempts to figure out motives of the poet's using particular figure of speech as well as what those figures of speech signify. The analysis of functions and meanings in this Kakawin Nitisastra is primarily based on literal analysis. Kakawin Nitisastra concerns on moral and religious teachings, as understood from the aim of the poet dadya prakrta nitisisastra inikêt lambang winakténg prajā 'may this teaching of ethics be spread in the society' (Ch. 1 Verse 1). So the analysis of functions and meanings take its foundation from this aim. In most verses, the motives of the poet are either hidden or implied, therefore, different figures of speech may have different functions and meanings within moral and religious environs.

In the analysis of functions and meaning, there are some interpretations concerning on the reasons of the poet's applying figures of speech in his works.

1. The figures of speech are used because there are some indications showing that the poet also presented (or referred) the script as criticism, advice or reminder to the king as a superordinate person. Therefore, the poet uses a high-context type of utterance so as not to directly abusive to the king.

2. In some parts, the poet refers to a king's characters and qualities. Figures of speech re used to imply the intended ideas.

3. Symbols, allegories, and similes are frequently used in traditional literary works, and they have become a kind of code of conduct for any writers.

4. The poet assumes that it is a sensitive matter when someone have to teach moral and religious values to others. Considering himself as a common man who is also prone to making mistakes, figures of speech are used to convey the values indirectly.

Some figurative speech intend to give examples of proper deeds. Figures of speech for this purpose are commonly similes, symbols, hyperboles and allusions. Sometimes, the poet refer to allegorical status to remind the readers of important figures of the past (names of kings in Vedic tradition, and so on). So, unintentionally, the poet tries to present an elaborately rich stock of stories and reference in his work by using just limited amount of words bound by metrical rules.

Another function of figurative language in Kakawin Nitisastra is to compare qualities, so that anyone reading the work may compare themselves to something good, for example proper deeds or characters of animals or plant, and thus take lessons from them. A more satiric intention than merely comparing qualities is to criticize, especially to argue against somebody's misbehavior in the society or towards oneself. From this 
criticism, some social taboos or improper conducts in old Javanese society is uncovered. One example is the anginang activity (eating betel leaves) in Chapter 8 Verse 2.

The last function of the figures of speech is to remind or to warn the readers. If somebody does something improperly, then they must be ready to accept the negative consequence. The poet stresses the importance of self-detachment to worldly possessions (as in Ch. 3 Verse 2 and in many more verses), since material possessions always results in quarrels and sorrow.

\section{Conclusion}

Kakawin Nitisastra is a compilation of ethics and moral teachings related to religious life. The analysis of figures of speech in this kakawin script revealed that it mainly uses symbolism, allegories and similes. The similes in the kakawin mostly compare someone to particular characters of animals, nuances or things. Meanwhile, metaphors are used commonly to imply someone's bad or good qualities by meaningful descriptions of how things work as well as how animals behave.

Since the functions and meanings of the figurative language are tightly related, the analysis of functions and meanings cannot be described separately. The meanings of the figurative speech are analyzed all at once with the functions since they are closely related. The functions of the figures of speech would not have been revealed if the meanings according to moral and religious context had not been analyzed. Also, the meanings would have not been clear if the functions had not contextually been reviewed.

\section{Reference}

Bonvillain, Nancy. (2003). Language, Culture, and Communication: the Meaning of Messages, Upper Sadle River: Pearson Education Inc.

Budiyasa, I Nyoman. (1997). Submata Pelajaran Tembang. Denpasar: Intan Pariwara.

Brown, Gillian and George Yule. (1993). Discourse Analysis. New York: Cambridge University Press.

Celce-Murica, Marianne. (2000). Discourse and Context in Language Teaching, New York: Cambridge University Press.

Creswell, J. W. (2008). Educational Research, Planning, Conducting, and Evaluating Quantitive and Qualitative Research, New Jersey: Pearson Education, Inc.

Davis, Miles. (2009). Sri Chanakya Nitisastra, The Political Ethics of Chanakya Pandit, available on http://www.philo sophy.ru/library/asiatica/indica/author s/kautilya/canakya niti sastra.html accessed on June 2018.

Denzin, Norman K. (1994). Handbook of Qualitative Research, Thousand Oaks: Sage Publications, Inc.

Endraswara, Suwardi. (2003). Metodologi Penelitian Kebudayaan, Yogyakarta: Gajah Mada University Press.

Frederik, Julia Tirajoh. (1988). English Poetry: An Introduction to Indonesian Students, Jakarta: LPTK.

Granoka, Ida Wayan Oka; I GedeS. Astra, I Gusti Ngurah Bagus et.al. (1984). Kamus Bahasa Bali Kuno-Indonesia, Denpasar: Departemen Pendidikan dan Kebudayaan Provinsi Bali.

Kawuryan, Megandaru W. (2006). Tata Pemerintahan Negara Kertagama Keraton Majapahit. Jakarta: Panji Pustaka. 
Kennedy, X.J. (1983). Literature, An Introduction to Fiction, Poetry and Drama. Toronto: Little, Brown and Company (Canada), Ltd.

Maker, I Gusti Ketut. (1988). Lontar Nitisastra, Collection of Gedong Kirtya, Singaraja. Reg. code: IIC.194/1.

Mardiwarsito, L. (1990). Kamus Jawa KunaIndonesia, Ende: Penerbit Nusa Indah.

Mulyana, Deddy. (2001). Metodologi Penelitian Kualitatif: Paradigma Baru Ilmu Komunikasi dan Ilmu Sosial Lainnya, Bandung: PT Remaja Rosdakarya Offset.

Mulyana, Slamet. (2006a). Tafsir Sejarah Nagarakrtagama, Yogyakarta: LKIS.

Mulyana, Slamet. (2006b). Menuju Puncak Kemegahan: Sejarah Kerajaan Majapahit, Yogyakarta: LKIS.

Nasution. (2003). Metode Penelitian Naturalistik Kualitatif, Bandung: Tarsito. Nunan, David. (1992). Research methods in Language Learning, Cambridge: Cambridge Language Teaching Library.

Perrine, Laurence. (1956). Sound and Sense: An Introduction to Poetry, California: Harcourt Brace Jovanovich Publications.

Tim Penyusun PGAHN 6 Tahun Singaraja. (1971) Niti Sastra dalam Bentuk Kakawin, Singaraja: Proyek Bantuan Lembaga Pendidikan Agama Hindu.

Prabhupada, A.C. Bhaktivedanti Swami. (1997). Bhagavad-gita As It Is, Mumbay: Bhaktivedanta Book Trust.

Prabhupada, A.C. Bhaktivedanti Swami. (2005). Lautan Manisnya Rasa Bhakti (Indonesian translation), Jakarta: Hanuman Sakti.

Robson, SO. (1978). "Pengkajian SastraSastra Tradisional Indonesia," in Jurnal
Pengkajian Bahasa dan Sastra, Vol. IV no. 6, July 1978.

Teeuw, A. (1984). Sastra dan Ilmu Sastra, Jakarta: Dunia Pustaka Jaya.

Tim Penyusun. (1999). Kakawin Nitisastra (in Balinese alphabet), Denpasar: Departemen Agama Provinsi Bali.

Willis, Bill. (2009). Allusion in Prose and Poetry. Available on http://www.wo rsleyschool.net/socialarts/allusion/pag e.html, accessed on June 2018.

Zoetmulder, P.J. (1983). Kalangwan, Selayang Pandang Sastra Jawa Kuno, Jakarta: Penerbit Djambatan.

Zoetmulder, P.J. and S.O. Robson. (2004). Kamus Jawa Kuna-Indonesia, Jakarta: Gramedia Pustaka Utama. 